\title{
Observations on the Centripetal and Centrifugal Xylems in the Petioles of Cycads. ${ }^{1}$
}

\author{
BY \\ M. J. LE GOC, Ph.D. (Rome), B.A. (CAntab.), \\ The Botany School, University of Cambridge.
}

With Plate XI and one Figure in the Text.

THE Cycads possess a number of characters which may be considered 1 as sign-posts pointing out possible paths of evolution. A noteworthy example is the peculiar structure of the foliar bundle with its double xylem arrangement, one portion centripetal, the other centrifugal (Pl. XI, Figs. 7-IO).

The significance of this unusual type of structure was first appreciated and carefully investigated by Mettenius. ${ }^{2}$ Most of the observers who followed him have interpreted the facts in relation to some special line of evolution from Palaeozoic plants. Hence it is that while facts are generally agreed upon, the interpretations differ according to the theories the facts are supposed to prove, corroborate, or favour.

We consequently find a class of writers considering the foliar bundle of Cycads as strictly mesarch, agreeing closely with the Lyginopteris (Lyginodendron), to which genus the Cycads are usually considered to be related. ${ }^{3}$

Another school opposes this view on the ground that it is based on a mere appearance: the bundle is apparently and not strictly mesarch. It is due to an inversion of the primary normal xylem. 'Pour certains auteurs, et ce sont les plus nombreux,' says Bertrand, 'le bois centripète n'est autre chose que le bois primaire normal retourné." ${ }^{4}$ Some authors, e. g. Chodat, would derive the centrifugal xylem from the centripetal xylem. 'Le bois centrifuge serait, d'après Chodat, du métaxylème détaché latéralement.' ${ }^{5}$

Bertrand's own opinion, in his collaboration with Renault, is summarized in these words: 'Un faisceau unipolaire diploxylé est donc un faisceau unipolaire normal dans la partie supérieure duquel le bois primaire s'est

1 A summary of this paper was given before Section $\mathrm{K}$ at the British Association, Birmingham, I9I3.

${ }^{2}$ G. Mettenius ('61).

3 W. C. Williamson and D. H. Scott ('96).

4 C. Eg. Bertrand et B. Renault ('86).

5 A. Sprecher ('07), p. 34. Cf. also R. Chodat, Sur quelques fossiles.

[Annals of Botany, Vol. XXVIII. No. CIX. January, I914.] 


\section{I84 Le Goc.-Observations on the Centripetal and Centrifugal}

réduit alors qu'il s'y est développé un tissu ligneux supplémentaire centripète ...' He then refers Cycads to the Poroxylon type.

The difficulty of deciding among these various interpretations led Chodat to suggest a reconsideration of the whole problem. ${ }^{2}$ I would not have ventured to undertake a part of this difficult task if Professor Seward had not invited me to do so and encouraged me during the investigation. I wish to take this opportunity of expressing to him my hearty thanks for his kind interest and advice during this work. The material, with the exception of a frond for which I am indebted to the Director of the Royal Gardens, Kew, was obtained from the Botanical Garden, Cambridge, and generously supplied by Mr. Lynch, the Curator, to whom also many thanks are due.

Five genera of Cycads, including seven species, and as far as possible of different ages, have been examined: Cycas circinalis and $C$. vevoluta, Stangeria paradoxa, Dioon edule, Ceratozamia mexicana, Encephalartos horridus and E. villosus.

The observations recorded in this communication were limited to the Cycadean leaf, and are restricted to the relation of the centripetal and centrifugal xylems to one another, and the relation of both to other tissues, these relations form the crucial point of the whole problem.

It was not until a preliminary account of my investigations had been written that I discovered a paper much on the same lines by Dr. Carano, of Rome. This paper, which is very detailed, has not perhaps received all the attention it deserves. ${ }^{3}$

\section{Observations.}

My observations lead me to conclude that the sketches and plates published do not usually represent the structure of a vascular bundle such as is found at the very base of a Cycad. This is, however, of great importance, as it is there that the most interesting changes occur; the transition from the stem-type of xylem into the petiolar arrangement of that tissue is seen along a few centimetres of petiole which immediately follow the stem.

The shoot of a fully developed petiole of a Cycas is first described as a basis for subsequent discussion. A few bundles pass into the leaf at the junction of petiole and stem. Their number varies much, but there are at least two main bundles to which the secondary ones seem to be related. These secondary bundles sometimes reunite with the main one, forming loops, before the latter begins to branch rapidly and forms part of the wellknown large $\omega$ set of bundles which will run up the petiole. This happens, say, at $\mathrm{I} \mathrm{cm}$. above the junction with the stem.

From our point of view the main bundles are the important ones, for they remain fairly constant for a distance of $2 \mathrm{~cm}$. or $3 \mathrm{~cm}$., even while they
1 C. Eg. Bertrand ('86).
2 R. Chodat ('08).
3 E. Carano ('03). 
give rise to other bundles which go to take their relative places in the general disposition of the foliar strands. Their forms vary considerably: they may be simple and collateral (Fig. 2), or concentric ${ }^{1}$ with parenchyma in the centre and medullary rays running radially all round, thus reproducing the structure of the stem or even of some peduncles (Fig. 3). A bundle may also be a compound structure, combining more or less completely the characters of the two first types mentioned (Fig. I). Intermediate types, as one would expect from such a variety of structures, are not infrequent.

But in this variety of forms there is a distribution of elements which remains constant at the base of the petiole. The xylem is entirely endarch or centrifugal (Figs. I-3). An internal protoxylem $(p x)$ is succeeded by numerous rows of lignified cells continued by cambium and phloem cells, with medullary rays running across the xylem, cambium, and phloem layers. This structure persists, say, for a distance of $2 \mathrm{~cm}$. from the base of the petiole, and then gradually changes in the course of the next $3-4 \mathrm{~cm}$. The cells in connexion with the protoxylem are no longer strictly centrifugal, but seem to run in a lateral direction. Only the central rows remain properly centrifugal (normal to the pith), undergoing, however, a process of reduction (Fig. 4).

This reduction is more and more apparent as we proceed up the petiole; the lateral rows pass behind the protoxylem, new independent groups of scattered lignified cells appear, and the centripetal xylem is initiated (Figs. 4 and 9).

At a higher level the centripetal xylem is more abundant than the centrifugal ; the gap which we observed behind, between the two lateral segments, is entirely closed; a complete ring is formed which soon breaks up on both sides (Figs. 7 and 8). There remains only a few centrifugal cells scattered in small groups and without any visible connexion with the centripetal xylem, except through a parenchymatous tissue of thin-walled cells in which it is embedded (Fig. IO). This is the ultimate form of structure met with practically throughout the petiole, apart from the $5 \mathrm{~cm}$. or $6 \mathrm{~cm}$. we have described. A last stage may be reached in which no trace of centrifugal xylem is left. This, however, is rare, and I have met with it only in the smaller bundles of the leaflets of Encephalartos horridus.

The above is a general survey of the natural and normal distribution of xylem elements in the petioles of Cycads at an adult stage.

Wound structures.-Other structures may be artificially induced. A young petiole of Cycas circinalis, $15 \mathrm{~cm}$. long, was wounded at the end of April; one of the wounds was transverse and not far from the base, the other wound was longitudinal and higher in the petiole. The leaf still grew well, though less luxuriantly than its companions of the same age.

On July I2, when it was about I metre long, it was cut and examined.

${ }^{1}$ See also H. Matte ('07), P1. I, Fig. 7 . 
The transverse wound was about $6 \mathrm{~cm}$. from the base; it had cut through some two-thirds or three-quarters of the area of the petiole, thus breaking the continuity of most of the foliar bundles. The sections prepared from the portions situated below the wound showed no abnormality, except a reduction of growth in the inactive and useless bundles as compared with their companions which had to carry out the whole work. This result is what might be expected in view of the fact that the injury cut off the supply of food from the leaflets. But just above the wound a remarkable phenomenon was observed. We must remember that at this height and even much below the wound the xylem was mainly centripetal xylem, disconnected from the centrifugal xylem. The cambium looked very active; it passed all round the bundle, producing xylem towards the centre and phloem on the outside (Fig. I2). There was secondary xylem formed even behind the centripetal xylem. Such a bundle is difficult to define; it looks concentric rather than mesarch. As we look further from the wound this peculiar structure gradually disappears till we finally reach a normal distribution of elements in the bundle, perhaps some $3 \mathrm{~cm}$. from the wound. It may be noted that this phenomenon occurred in a great number of the severed bundles. In connexion with these a new structure was induced. A large bundle built up of stout lignified cells, having much the appearance of a transfusion tissue, brought all the severed bundles into communication with the unwounded bundles, and allowed a transport of material to and from the channels interrupted by the wound, like a short loop-line connecting the ends of a section of rails under repair (Fig. I3).

The longitudinal cut was narrow but long, its distance from the base varying between $10 \mathrm{~cm}$. and $20 \mathrm{~cm}$. It was situated near the first leaflet and higher in the petiole. The leaf reacted against the injury by repairing the damage done and filling up the gap with new tissue, disposed in regular rows quite distinct from the rest of the petiole. A large bundle, giving rise to this tissue, originated in the internal margin of the wound. Its cells are pitted and run somewhat irregularly, showing a tendency to imitate the transfusion tracheides met with lower down just above the transverse cut. The bundles next to the wound were also considerably affected; they became closed and concentric, showing new regions of growth. This influence is less marked further away from the wound. The meaning of these traumatic structures is considered later. Bertrand and Renault tested the effect of longitudinal wounds, but they considered the results as accidental and of no significance.

\section{Interpretation.}

The disposition of the vascular bundles at the very base of the petiole, as we have seen, offers a striking appearance. The various forms (Figs. I-3) they assume are, I believe, of no phylogenetic importance, but serve to 
show the facility with which bundles or steles can adapt themselves to either morphological or physiological requirements. Their main significance is that they illustrate the need of caution in basing phylogenetic relationships on morphological structures which may be the result of long and progressive efforts of the plant to adapt itself to different needs.

More worthy of notice is the special and constant arrangement of the elements themselves, with their regular rows of xylem, cambium, and phloem, separated by distinct medullary rays (Figs. I and 5). Such a structure would naturally suggest a secondary growth, an assumption made by several writers with less definite or clear sections before them, at least judging from the sketches they have published. ${ }^{1}$ I was too ready to make the same assumption when Professor Lang, of Manchester, warned me that there are similar occurrences in primary structures. A section across a petiole of Ginkgo, for instance, would show it clearly. ${ }^{2}$ Such a structure may be a predetermined arrangement and not the result of cambial activity. This objection is a most serious one, attacking the very foundation of the argument and, consequently, the conclusion itself. We must therefore recast the whole proof or give up the assertion.

It is a difficult problem to work out critically owing to the impossibility of studying the same individual bundle at different ages; on the other hand, the structure of the bundle varies considerably and rapidly with the distance from the stem or even at the same level on the petiole.

There is, however, a possible solution. Taking petioles of different ages from the same species and the same stem, which have had the same chances and the same opportunities for growth, the only difference being that of age, we may count the number of cells contained in a row passing straight from the cambium to the first protoxylem cell. To be fair we must take for comparison the highest number of cells found in a row at different ages in different petioles, or we might also use averages; the former method was followed.

The present account is based mainly on Cycas revoluta and Cycas circinalis. The youngest petioles used were about $10 \mathrm{~cm}$. long. Dr. Carano gives a sketch of a still younger specimen. ${ }^{3}$ His drawing would seem to lend a strong support to my argument, but it is safer not to use it as we do not know the age of the stem from which the petiole was taken.

The oldest petiole (probably four years) of Cycas circinalis examined showed straight rows of 22 lignified cells, an average of $16-20$ being of common occurrence (Fig. I). A specimen two years old numbered I6 cells. Other petioles of the present year showed a decrease corresponding with their age, the maximum being about $\mathrm{I}_{2}$ in a specimen $40 \mathrm{~cm}$. long. A young leaf of Cycas revoluta, $10 \mathrm{~cm}$. long, possessed rows

1 E. Carano ('03), and C. Eg. Bertrand et B. Renault ('86).

${ }^{2}$ A. Sprecher ('07), p. 64.

${ }^{3}$ E. Carano ('03), Tav. ix, Fig. 9. 
of Io cells (Fig. 6), as compared with 16 or 18 in a leaf two years old belonging to the same plant (Fig. 2).

Apart from numerical results, the mere look of the sections would force one to conclude that secondary growth occurs in the centrifugal xylem at the base of the petioles. This view is confirmed by the examination of the cells near the cambium in a moderately old petiole over I metre long; the cells at the ends of the rows are evidently undergoing a process of lignification, for they are thinner than their neighbours, stain less deeply, giving, in fact, all the transitional shades specially visible in sections stained with gentian violet and orange $G$.

It seems therefore proved that the centrifugal xylem at the base of the petiole is a secondary growth, at least in its main bulk, and we have to disagree with Dr. Scott, who holds that 'the centrifugal part of the wood must be regarded as a primary structure, though in certain cases it may receive subsequent addition from a cambial layer'. ${ }^{1}$ This small allowance for secondary growth is at least too limited.

Following the bundle still higher, we have seen the ring of xylem breaking up altogether; the two xylems are completely separated by a layer of thin-walled cells; the protoxylem is in contact with the centripetal xylem, but not, generally speaking, with the centrifugal xylem (Fig. IO). No centrifugal xylem is found in young petioles at this level where the centripetal xylem is well developed. It is produced later than the centripetal xylem, and appears to be in continuity with the radial rows of meristem cells. There is at least no definite line between the large amount of undoubted secondary centrifugal xylem at the base of the petiole and the much smaller amount found at the higher level, and we are inclined to agree with Dr. Carano, who regards the latter as also of secondary origin: 'd'origine secondaria s'intende bene, ultimi avanzi del legno centrifugo.' ${ }^{2}$

From these observations I am led to inquire into the relations between the centripetal xylem and centrifugal xylem. I shall deal with them only in the light of my own observations.

The gradual bending backwards of the lateral centrifugal xylem as one passes away from the base would seem to favour the inversion theory (Figs. 4 and 9). There is also a tendency in the phloem to follow this motion, though, in fact, it lags a good deal behind. But perhaps this inversion is more apparent than real. The theory is based upon an assumption which needs proof-namely, that it is the same xylem which takes up these different positions.

Not only is proof lacking, but the facts themselves seem to contradict the hypothesis. We have seen that the centrifugal xylem at the base of the petiole is a secondary growth, at least in its main bulk, or, with the

1 W. C. Williamson and D. H. Scott ('96).

2 E. Carano ('03). 
exception of the protoxylem, perhaps entirely secondary, for it is not easy to see where to draw a limit in rows of cells which look so uniform. On the other hand, it would be easy to show that the centripetal xylem is a primary structure, the result of the division of the meridesmogen strand; there is no sign of cambium activity, the cells are distributed in their proper place a long time before they are gradually lignified. In fact, the primary nature of the centripetal xylem is now generally admitted.

But, if this is the case, it is difficult to regard a primary structure as the continuation of a secondary one. The continuity theory breaks down here altogether: to be in succession or in contact is a different thing from being continuous; to be in succession may mean only juxtaposition; to be continuous implies, moreover, community of origin or derivation. Such structures could not therefore be called homologous, and still less identical with each other. It is much like the Poroxylon described by Bertrand. ${ }^{1}$ The difference in the nature of the xylem cells could also be quoted in favour of this statement; but this proof is of little value, as the nature of the centripetal xylem varies so much and so rapidly with the distance from the protoxylem, giving in succession spirally thickened, reticulate, annular, scalariform, pitted, multiseriate pitted tracheides (Fig. I I).

There is a remarkable resemblance between the vascular tissue of the Cycad petiole and that of a leaf of Cordaites, as described by Dr. Marie Stopes. $^{2}$ The cells forming the inner sheath are very like the reduced centrifugal xylem of Cycads both in longitudinal and transverse sections, the only visible difference being the position. In the Cordaites described they are in close relation to the bundle-sheath, but in many leaves of this genus a large amount of phloem separates the centrifugal xylem from the bundle-sheath. There seems to be no adequate reason for regarding the inner sheath as other than the centrifugal xylem.

Dr. Carano insists strongly on the fact that the centrifugal xylem is in continuation with the centripetal xylem or even the protoxylem. But this relation is more apparent than real, if we admit that the centrifugal xylem and centripetal xylem are juxtaposed rather than continuous. It is only at the very base that the xylems join hands and that the protoxylem becomes common to both.

The facts seem to bring out the independence of the xylems; they are independent in origin and nature but are juxtaposed to carry out their functions ; in fact, in places they are brought into communication with one another by transfusion cells, or by the laterally stretched wings of the centripetal xylem. They are continuous physiologically but not morphologically. This interpretation has much in common with the view supported by Bertrand and Renault. The centrifugal xylem is the continuation of the

1 C. Eg. Bertrand et B. Renault ('86). Cf. also D. H. Scott, Studies in Fossil Botany, I9og.

2 Marie C. Stopes ('03). 
normal centrifugal xylem of the stele and the girdles; the centripetal xylem is an independent tissue, probably the remnant of an ancient and more developed structure- a conclusion supported or suggested by the structure

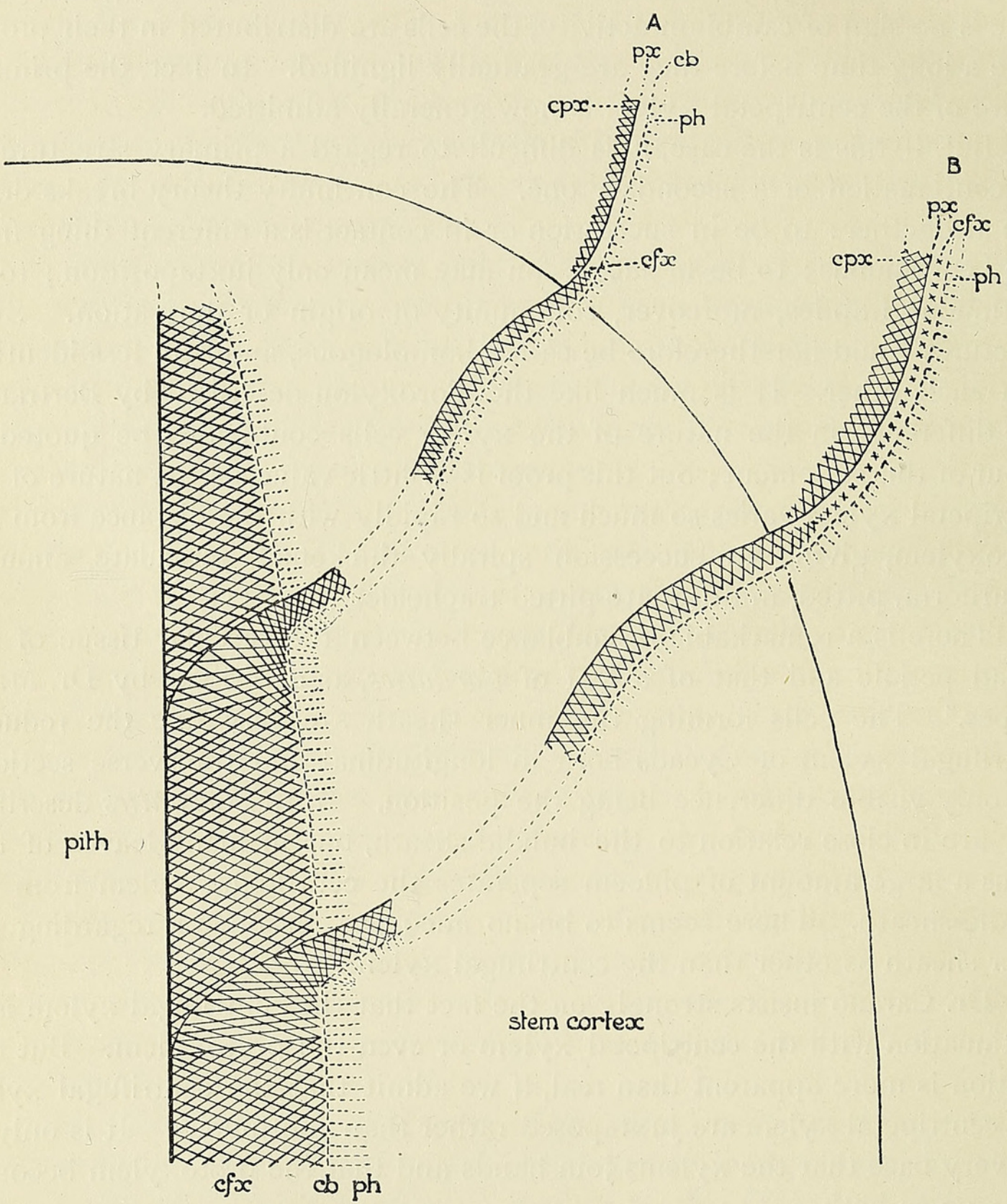

TEXT-FIG. Longitudinal section of apex of stem and of petiole, showing relation between centripetal and centrifugal xylem. $c p x$, centripetal xylem; $p x$, protoxylem; $c b$, cambium ; $c f x$, centrifugal xylem; ph, phloem. A, younger petiole without centrifugal xylem except at base; $\mathrm{B}$, older petiole with centrifugal xylem throughout, but not in connexion with the protoxylem except at the base before the centripetal xylem appears.

of several Palaeozoic types. ${ }^{1}$ It is worthy of remark that the first centripetal xylem elements to be found at the base are often scattered and unconnected with the centrifugal xylem. The text-figure shows the relation between the two xylems.

1 D. H. Scott, Ann. Bot., I9I 2, p. IoI4. Cf. also New Phyt., 1902, pp. 25-30. 
Bertrand bases his assertion on the fact that the centrifugal xylem comes out of the stem undistorted; but this is hardly an argument, as the centrifugal xylem might well be inverted higher up in the petiole, as it apparently is. His other argument is based on the idea that the protoxylem attached to the centrifugal xylem gradually disappears. There is much to be said for such a view, only that it is not easy to show that this protoxylem is disconnected and different from the protoxylem which accompanies the centripetal xylem. ${ }^{1}$

It would seem that at least the centripetal xylem has been reduced at one of its extremities; the few blind xylem elements scattered at the base of the petiole indicate that they formerly extended lower down, perhaps even into the stem; 'it has only survived as long as it has because of the conservatism of the foliar bundles;' ${ }^{2}$ while the centrifugal xylem might possibly have been secondary all along its course, approaching some types of Palaeozoic fossils, e.g. Poroxylon.

The terminology used by different observers reflects accurately the theories these observers have in mind. According to Dr. Scott, the term mesarch 'implies that the development begins in the middle of the strand of wood '. ${ }^{3}$ It is difficult to find such a bundle in the petiole of Cycads where the protoxylem is connected $(a)$ either with a xylem which is entirely centrifugal, or $(b)$ with a xylem which is centripetal, in which case the protoxylem and the centrifugal xylem of secondary origin are usually disconnected.

The French school, on the contrary, constantly employ the word 'diploxylic'-'diploxylé - because 'they oppose the two parts to one another as "bois centripète" and "bois centrifuge", and regard them as distinctly different things' (Solms-Laubach). ${ }^{4}$ Then Solms-Laubach adds that if the word 'mesarch' had been invented before the French authors published their results, 'we might perhaps have been spared this misconception.' This remark is tantamount to saying that a hypothesis may be derived from a coined word rather than a definition or word be made, created if necessary, to fit in with a theory.

\section{Wound-structures.}

Do the structures artificially induced throw any light on this problem? There is now a tendency to consider such structures as primitive. In this view the anatomical modifications brought about in the petiole of Cycas by cuts would be most instructive. The bundles much influenced looked concentric; it would then follow, according to this theory, that the foliar bundles were originally concentric, that they have lost this character and passed through all the stages met with in passing away from a wound.

1 C. Eg. Bertrand et Renault ('86).

3 W. C. Williamson and D. H. Scott ('96).

2 D. H. Scott, New Phyt., I902, p. 29.

4 Solms-Laubach ('91), pp. ${ }_{25}^{6-7}$. 
Also these wound-induced tissues imitate structures often met with at the base of a petiole. It would be reasonable to suppose that all the phases in the evolution of the vascular bundle can be traced in a living petiole of a Cycad. Unfortunately the principle at the base of this argument is not proved in its generality, and to quote the Cycas wounds as an instance would obviously be a vicious circle.

It is, perhaps, more likely that such structures are developed in response to a physiological need. As a general outlook no one can help seeing that the anatomy of plants corresponds to a physiological function or purpose. Through some mechanism of life they must have been developed in relation to such a need. In this instance the increased activity of the cambium in the bundles tends to answer such a purpose by increasing the area of the bundles as their number is reduced. Also the new bundles of transfusion cells are evidently adapted to fulfil a function, a need. Why this is so could not, perhaps, be answered by Experimental Botany, which is more concerned with the question how it is done.

Thus, reduced to a physiological interpretation, these structures artificially induced are without any direct bearing on the phylogenetic interpretation of the bundle. Our final conclusions are therefore:

I. At the very base of the petiole the structure of the vascular bundles of Cycads is entirely centrifugal, and assumes different forms, concentric, collateral, or the combination of both.

2. The centrifugal xylem at the base is, at least in its main bulk, a secondary growth. This is indicated by the regular rows of xylem, cambium, and phloem, separated by medullary rays, and proved by the study of petioles at different ages.

3. The centripetal xylem is a primary structure laid down at an early age, but only gradually lignified.

4. The centrifugal xylem and centripetal xylem are probably distinct in origin, juxtaposed in response to physiological demands but morphologically discontinuous.

5. During most of the course along the petiole the two xylems remain distinct, therefore the bundle is more properly called pseudo-mesarch ${ }^{1}$ or diploxylic.

6. The two xylems overlap at their ends. The remains of centripetal xylem scattered at the base might point to a time when it ran further down, perhaps into the stem.

1 A word suggested by Prof. A. C. Seward. 


\section{LITERATURE CITED.}

1. Bertrand, C. Eg., et Renault, B.: Remarques sur les faisceaux foliaires des Cycadées actuelles. Arch. Bot, du N. de la France, i 886.

2. Carano, E.: Contribuzione alla conoscenza della morfologia e dello sviluppo del fascio vascolare delle foglie delle 'Cicadacee'. Annali di Botanica, Roma, I903.

3. Chodat, R.: (a) Sur quelques fossiles végétaux. Bulletin de l'Herbier Boissier, $2^{\mathrm{e}}$ série, tome vii; (b) Archives des Sciences physiques, tome xxvi, 1908.

4. Matte, H. : Recherches sur l'appareil libéro-ligneux des Cycadacées. Mémoires de la Société Linnéenne de Normandie, vol. xxii, Caen, 1907.

5. Metrenius, G. H. : Beiträge zur Anatomie der Cycadeen. Abh. K. Sächs. Gesellsch. Wiss., vol. vii, I86I, pp. 565-608.

6. Scott, D. H. : (a) Studies in Fossil Botany. London, I909; (b) Annals of Botany, I9I 2 ; (c) New Phytologist, Feb., 1902.

7. Solms-Laubach, H., Graf : Fossil Botany. English translation, i 89 I.

8. Sprecher, A.: Le Ginkgo Biloba. Genève, 1907.

9. Stopes, Dr. Marie C. : New Phytologist, I903, pp. 9I-8.

10. Williamson, W. C., and ScotT, D. H. : Further Observations on the Plants of the Coal Measures. Phil. Trans. Roy. Soc., London, vol. B. clxxxvi, I896, pp. 703-79.

\section{EXPLANATION OF PLATE XI.}

Illustrating Dr. Le Goc's paper on Centripetal and Centrifugal Xylem in the Petioles of Cycads.

Fig. I. Cycas circinalis, four years old, base of petiole, a compound structure. $c l b=$ collateral bundle ; $c c b=$ concentric bundle; $p x=$ protoxylem; $c f x=$ centrifugal $x y l e m ; p h=$ phloem; $m r=$ medullary ray.

Fig. 2. C. revoluta, two years old, base of petiole. $c l b=$ collateral bundle.

Fig. 3. C. revoluta, base of petiole. $c c b=$ concentric bundle.

Fig. 4. C. circinalis, near base. $c p x=$ centripetal xylem.

Fig. 5. C. circinalis, present year, base of petiole $40 \mathrm{~cm}$. long.

Fig. 6. C. revoluta, present year, base of petiole $10 \mathrm{~cm}$. long.

Fig. 7. Encephalartos horridus, near base; $c p x$ and $c f x$ separate.

Fig. 8. Stangeria paradoxa, near base; $c p x$ and $c f x$ separate.

Fig. 9. Cycas circinalis, near base; $c p x$ independent.

Fig. I0. C. circinalis, far from base; $c f x$ separate from $p x$ and $c f x$.

Fig. 11. C. circinalis, far from base. Longitudinal section showing different forms of tracheides.

Fig. 12. C. circinalis, wound structure, secondary $c p x$.

Fig. I3. Large bundle of transfusion tissue $(t f b)$. 

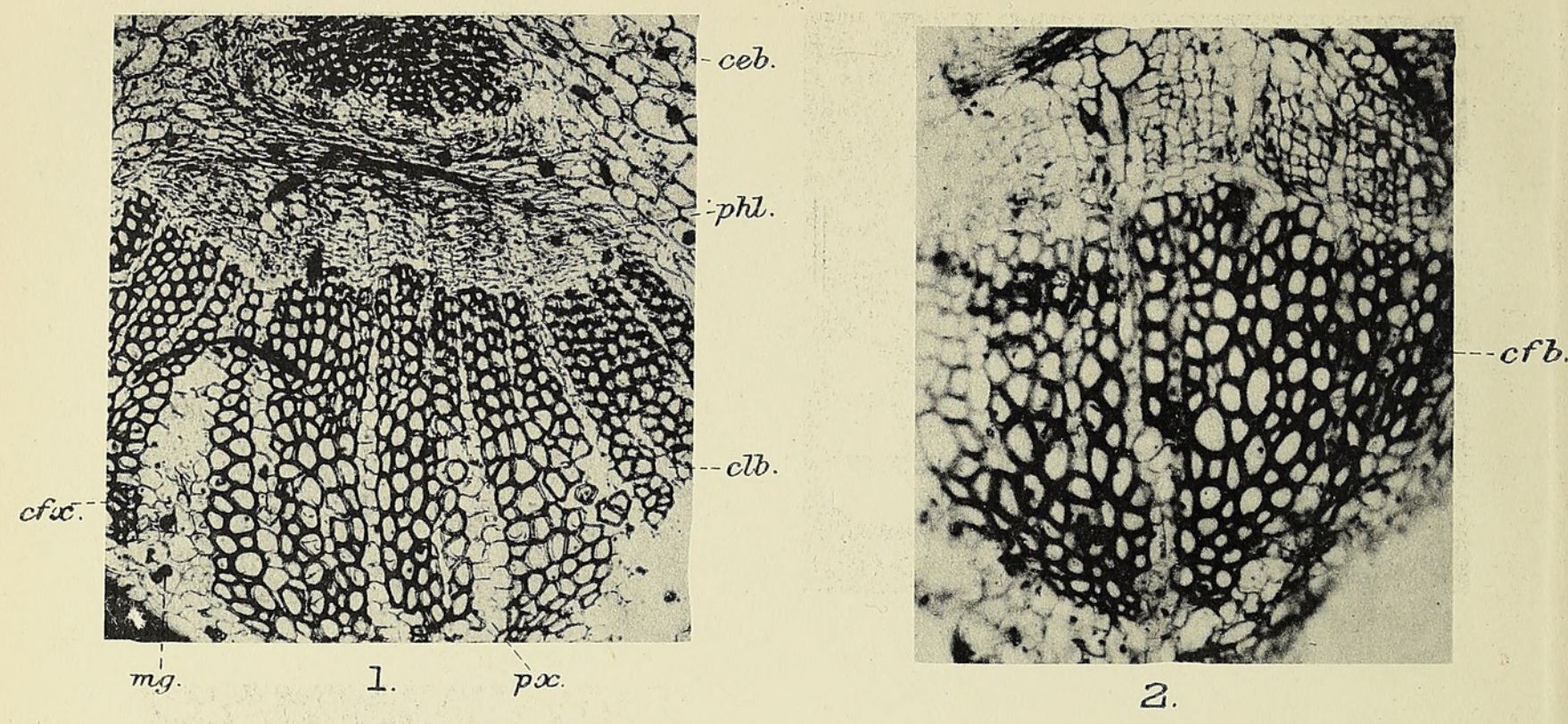

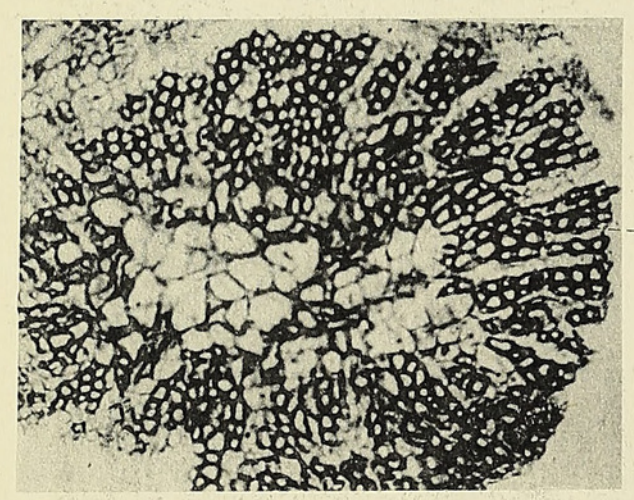

3. $\operatorname{ccb}$.
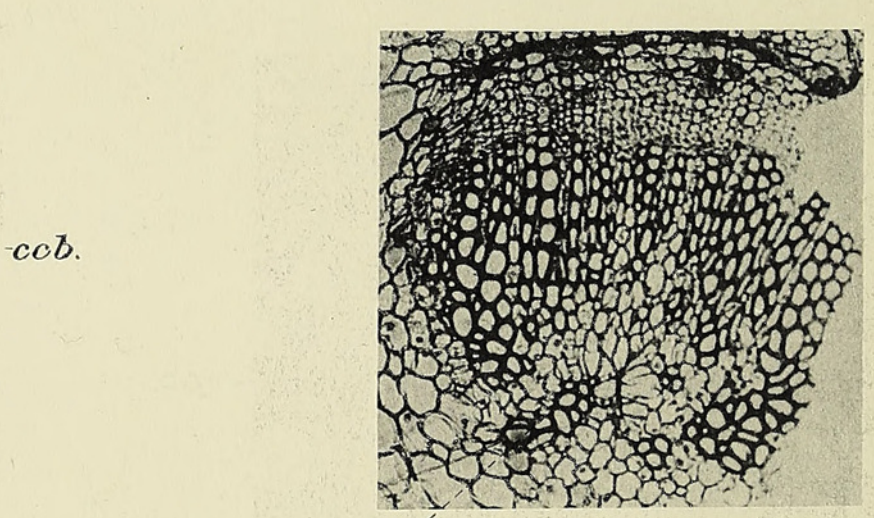

cps. 4.

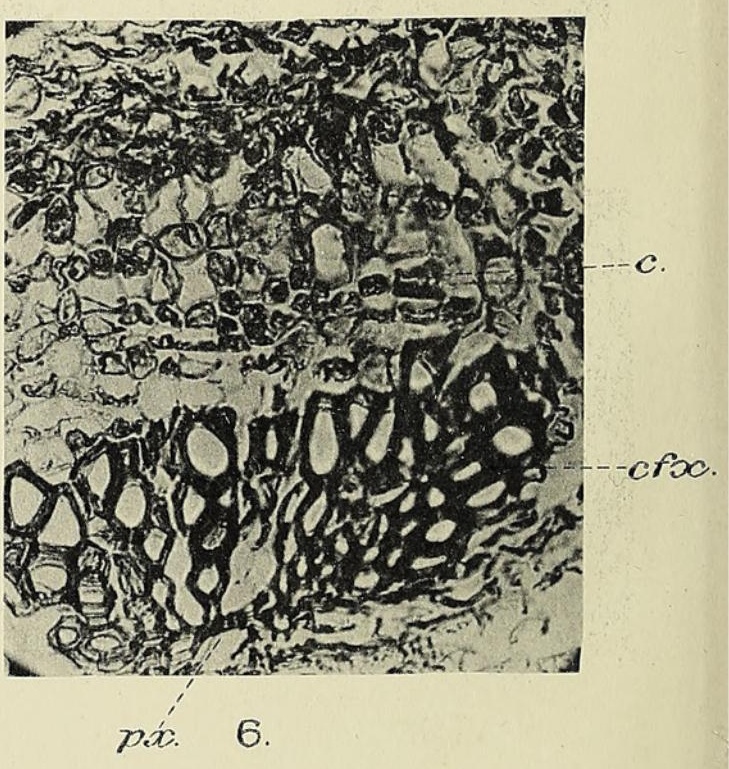




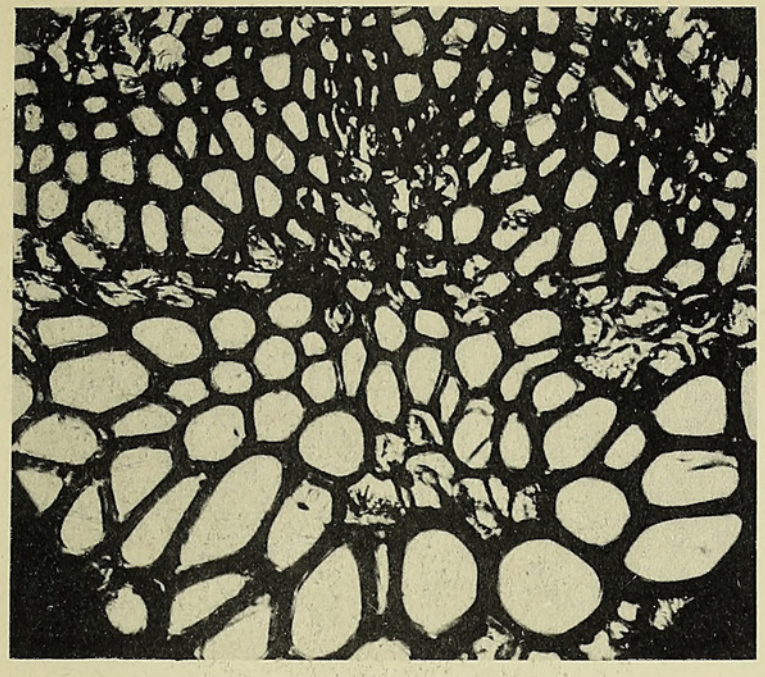

7.

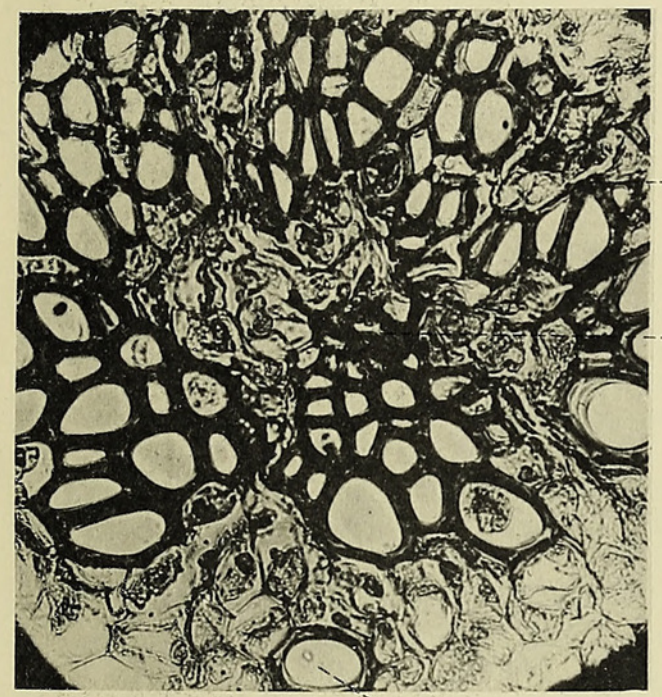

9. ¿pac.
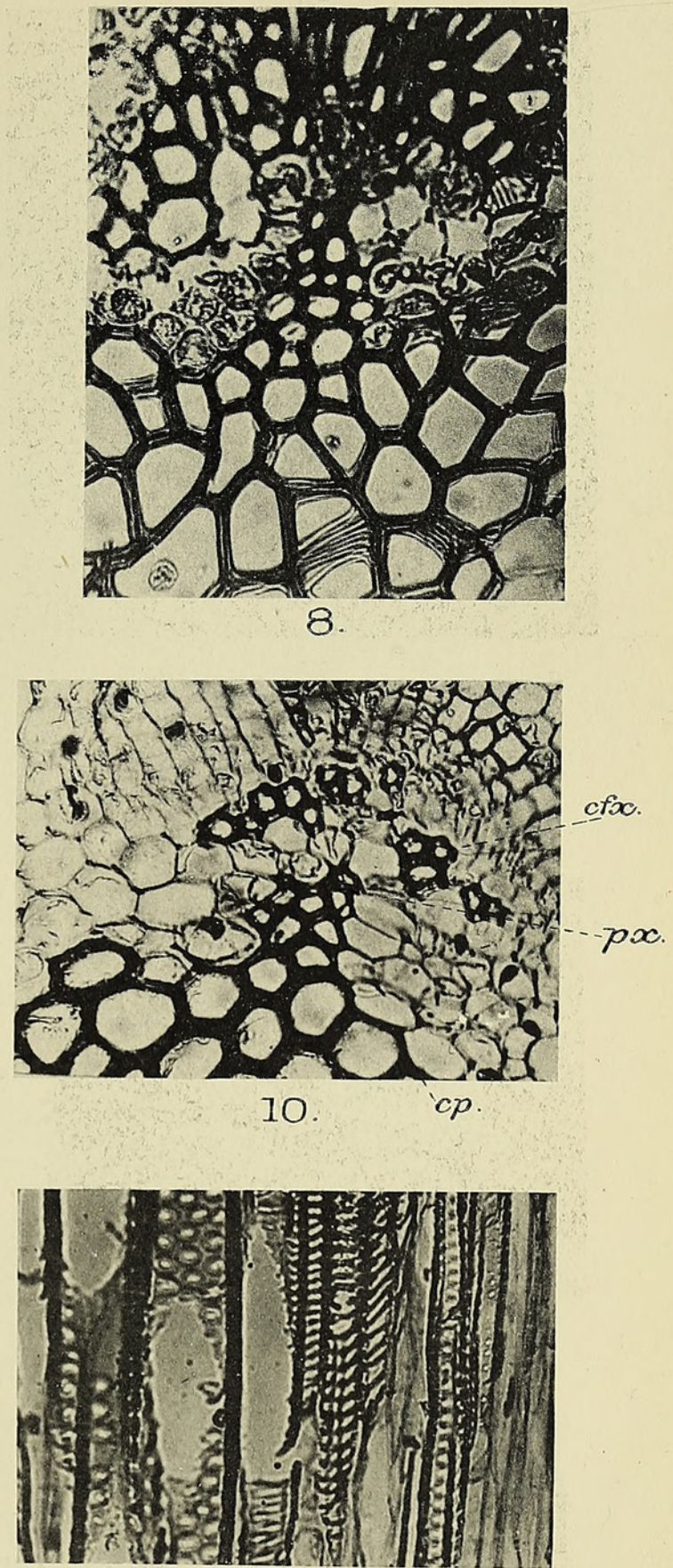

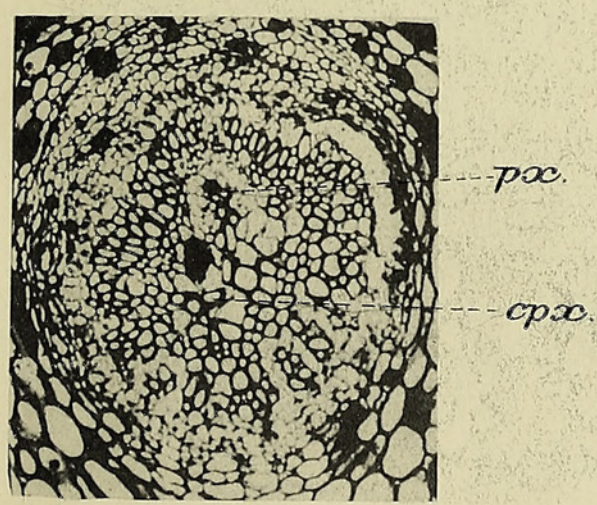

12.
11.

ctic

poo.

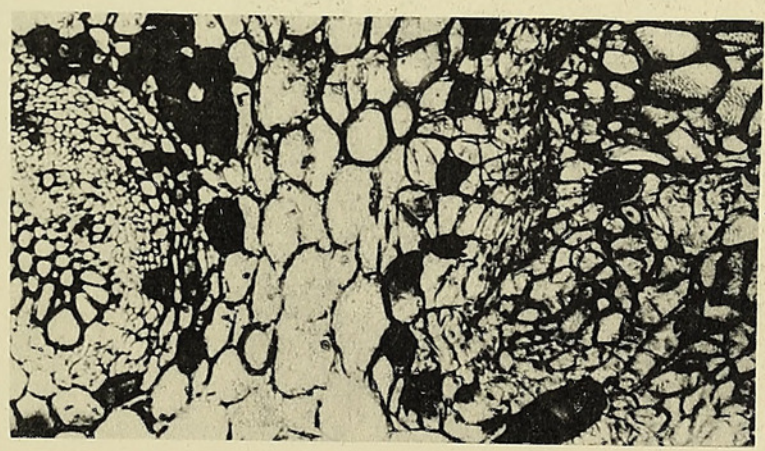

13. 


\section{$2 \mathrm{BHL}$ Biodiversity Heritage Library}

Le Goc, M. J. 1914. "Observations on the centripetal and centrifugal xylems in the petioles of Cycads." Annals of botany 28, 183-193.

https://doi.org/10.1093/oxfordjournals.aob.a089494.

View This Item Online: https://www.biodiversitylibrary.org/item/236856

DOI: https://doi.org/10.1093/oxfordjournals.aob.a089494

Permalink: https://www.biodiversitylibrary.org/partpdf/320015

\section{Holding Institution}

Smithsonian Libraries

\section{Sponsored by}

Biodiversity Heritage Library

\section{Copyright \& Reuse}

Copyright Status: Not in copyright. The BHL knows of no copyright restrictions on this item.

This document was created from content at the Biodiversity Heritage Library, the world's largest open access digital library for biodiversity literature and archives. Visit BHL at https://www.biodiversitylibrary.org. 